\title{
Studi Deskriptif Peran Guru Sebagai Pendidik dalam Mengembangkan Karakter Disiplin Siswa di Kelas IV A SD Negeri 01 Kota Bengkulu
}

\author{
Meivia Anggela \\ Universitas Bengkulu \\ Meiviaanggela@gmail.com \\ Osa Juarsa \\ Universitas Bengkulu \\ Juaraosa@yahoo.com \\ Bambang Parmadi \\ Universitas Bengkulu \\ bparmadie@unib.ac.id
}

\begin{abstract}
This study aims to describe the role of teachers as educators in developing the discipline character of students in class IV A 01 Kota Bengkulu Elementary School. This type of research is qualitative research, with descriptive research methods. The subjects of the study were the principal, grade IV A teachers, and grade IV A students. Data collection techniques used observation, interviews, and documentation. Data analysis was performed by data collection, data condensation, data presentation, and drawing conclusions. Testing the validity of the data using extended observations, increasing perseverance and triangulation. The results of this study indicate that the role of the teacher as an educator in developing the character of student discipline has been carried out in class IV A. The role of the teacher in developing the character of student discipline consists of as motivators, facilitators and evaluators. As a motivator the teacher has given encouragement to students to always be disciplined in the classroom, as a facilitator the teacher has provided the facilities needed by students to develop the character of their discipline and as an evaluator the teacher has also conducted an evaluation to see the extent of the development of the discipline character of students in the class.
\end{abstract}

Keywords: The Role Of Teachers, Character, Discipline

\section{Pendahuluan}

Guru merupakan orang tua kedua bagi siswa di sekolah, sebagai orang tua guru memiliki banyak peran di sekolah salah satunya peran sebagai seorang pendidik. Peran guru sebagai seorang pendidik yaitu guru harus mampu menanamkan serta mengembangkan sikap dan karakter yang ada pada diri siswa salah satunya karakter disiplin. Ini dilakukan agar siswa memiliki sikap dan karakter yang sesuai dengan nilai, norma serta aturan yang berlaku baik dilingkungan sekolah, rumah maupun lingkungan masyarakat. Hal ini sesuai dengan pendapat Subini (2012:16) bahwa peran guru sebagai seorang pendidik merupakan peran-peran yang berkaitan dengan tugas-tugas memberi bantuan dan 
dorongan baik tugas pengawasan dan pembinaan serta tugas yang berkaitan dengan mendisiplinkan anak agar anak tersebut menjadi patuh terhadap aturan-aturan sekolah dan norma hidup dalam keluarga dan masyarakat. Artinya peran guru sebagai seorang pendidik yaitu guru harus mampu membantu mendidik siswa dalam mengatasi pemecahan masalah yang dihadapi oleh siswa.

Dalam hal ini guru sebagai pendidik bukan hanya mendidik siswa dibidang ilmu pengetahuan saja tetapi juga menyangkut dalam pengembangan kepribadian/perilaku dan pembentukan nilai-nilai pada siswa agar sesuai dengan norma dan aturan yang berlaku salah satunya membantu mendidik siswa dalam mengembangkan karakter disiplinnya. Dengan disiplin siswa akan menjadi terbiasa untuk mematuhi norma serta aturan-aturan yang berlaku baik dilingkungan sekolah, rumah maupun masyarakat. Hal ini sesuai dengan pendapat Kharisma (2018:133) bahwa disiplin sangatlah penting dan dibutuhkan oleh setiap siswa, disiplin menjadi prasyarat bagi pembentukan sikap, perilaku dan tata tertib kehidupan dalam berdisiplin, disiplin akan mengantar seorang siswa sukses dalam belajar. Disiplin yang dimiliki oleh siswa akan membantu siswa dalam tingkah laku sehari-hari, baik disekolah maupun di luar sekolah. Aturan yang ada di sekolah akan bisa dilaksanakan dengan baik jika siswa sudah memiliki karakter disiplin yang ada dalam dirinya. Oleh karena itu, peran guru sebagai pendidik disekolah sangat dibutuhkan terutama untuk membantu siswa dalam mengembangkan karakter disiplinnya di dalam kelas.

Berdasarkan penelitian yang pernah dilakukan oleh Fakthur Rohman pada tahun 2018 dengan judul "Peran Pendidik dalam Pembinaan Disiplin Siswa Disekolah/Madrasah" dengan hasil yang diperoleh bahwa peran guru sebagai pendidik sangat besar terhadap keberhasilan peserta didiknya. Pendidik harus mampu menjadi contoh yang baik bagi peserta didiknya. Terutama dalam pembinaan disiplin siswa disekolah/madrasah, untuk memudahkan dalam menanamkan sikap disiplin kepada siswa agar dapat terlaksana dengan baik dan siswa bersungguh-sungguh dalam menjalankannya maka harus dimulai dari pendidik itu sendiri. Kemudian penelitian yang ditulis oleh Arifudin pada tahun 2015 dengan judul "Peranan Guru Terhadap Pendidikan Karakter Siswa di Kelas V SDN 1 SILUMAN" dengan hasil yang diperoleh bahwa guru memiliki peranan penting dalam menanamkan nilai-nilai karakter terhadap siswa sebagai bentuk perhatian guru untuk mengembangkan karakter siswa agar dalam setiap proses pembelajaran bisa berjalan sesuai dengan yang diharapkan. Salah satunya karakter disiplin, guru telah mampu memberikan motivasi dan dorongan terhadap siswa untuk terus giat belajar sehingga karakter disiplin siswa dapat terbentuk secara bertahap sesuai dengan harapan guru.

Kedua penelitian tersebut, menunjukkan bahwa karakter disiplin siswa dapat berekembang dengan adanya peran guru sebagai seorang pendidik yang selalu membantu siswa secara terus menerus dalam mengembangkan karakter disiplinnya. Oleh karena itu, peran guru sebagai seorang pendidik menjadi hal yang sangat penting dalam mengembangkan karakter disiplin siswa. Tanpa adanya peran dari guru, maka karakter disiplin siswa tidak akan bisa berkembang sesuai dengan yang diharapkan.

Berdasarkan data awal penelitian melalui observasi dan wawancara yang telah dilakukan peneliti di kelas IV A SD Negeri 01 Kota Bengkulu diperoleh informasi bahwa guru telah melakukan perannya sebagai seorang pendidik dalam mengembangkan karakter disiplin siswa di kelas IV A. Walaupun guru telah melakukan perannya dalam mengembangkan karakter disiplin siswa namun masih saja terdapat beberapa siswa yang karakter disiplinnya belum sepenuhnya berkembang di dalam kelas. Karena, masih terdapat beberapa siswa yang terlambat masuk kelas dan belum sepenuhnya menaati peraturan kelas. Dari fenomena yang 
terjadi tersebut maka tujuan dalam penelitian ini yaitu untuk mendeskripsikan peran guru sebagai pendidik dalam mengembangkan karakter disiplin siswa di kelas IV A SDN 01 Kota Bengkulu.

\section{Metode}

Jenis penelitian ini adalah penelitian kualitatif, dengan menggunakan metode deskriptif. Penelitian ini bertujuan untuk mendeskripsikan peran guru sebagai pendidik dalam mengembangkan karakter disiplin siswa di kelas IV A. Penelitian ini dilaksanakan di SD Negeri 01 Kota Bengkulu, yang beralamat di Jalan. Prof. Dr. Hazairin, SH, Kecamatan. Teluk Segara, Provinsi Bengkulu. Penelitian ini dilaksanakan pada bulan Maret-Mei. Dalam melakukan penelitian, pasti tentunya ada yang dijadikan sebagai subjek. Subjek penelitian ini adalah orang yang menjadi sasaran untuk dikumpulkan datanya. Pada penelitian ini, subjek yang dijadikan peneliti yaitu Kepala Sekolah SDN 01 Kota Bengkulu, Guru kelas IV A, dan Siswa kelas IV A. Data dan sumber data yang digunakan dalam penelitian ini yaitu data primer dan data sekunder. Data primer adalah data yang diperoleh dari hasil interview (wawancara) dan pengamatan (observasi), sedangkan data sekunder adalah data yang diperoleh dari dokumen-dokumen sekolah.

Adapun sumber data dalam penelitian ini adalah orang-orang yang menjadi sumber data disebut informan. Artinya tidak setiap orang dalam lembaga yang diteliti bisa menjadi informan, sebab yang diteliti hanya informan ekspert. Informan ekspert adalah orang-orang yang bertanggung jawab, benar-benar mengetahui, menguasai dan banyak terlibat dalam kegiatan yang akan diteliti. Dalam penelitian ini informan pertama yang diwawancarai peneliti yaitu guru kelas IV A. Karena guru kelas lebih mengetahui sejauh mana perkembangan karakter disiplin siswa di dalam kelas. Informan selanjutnya yang di wawancarai peneliti yaitu kepala sekolah dan siswa kelas IV A. Dalam penelitian ini tidak semua siswa dijadikan informan peneliti hanya mengambil beberapa sampel yang akan dijadikan informan. Instrumen dan teknik pengumpulan data yang dilakukan peneliti menggunakan observasi, wawancara dan dokumentasi. Teknik analisis data menggunakan model Miles dan Huberman yaitu pengumpulan data (data collection), kondensasi data (data condensation), penyajian data (data display), dan penarikan kesimpulan (conclusion drawing/verification). Keabsahan data menggunakan perpanjangan pengamatan, meningkatkan ketekunan dan triangulasi.

\section{Hasil}

Berdasarkan penelitian yang telah dilakukan peneliti di kelas IV A SDN 01 Kota Bengkulu terlihat guru telah melakukan perannya sebagai seorang pendidik dalam mengembangkan karakter disiplin siswa. Peran guru sebagai pendidik dalam mengembangkan karakter disiplin siswa dalam penelitian ini terdiri dari sebagai motivator, fasilitator dan evaluator. Adapun peran guru sebagai motivator dalam mengembangkan karakter disiplin siswa di deskripsikan sebagai berikut.

\section{Peran Guru Sebagai Motivator}

Berdasarkan penelitian yang telah dilakukan peneliti di kelas IV A SDN 01 Kota Bengkulu melalui observasi, wawancara dan dokumentasi diperoleh informasi bahwa guru telah melakukan perannya sebagai motivator. Hal ini terlihat ketika sebelum memulai kegiatan pembelajaran guru selalu memberikan dorongan semangat kepada siswa agar masuk kelas tepat waktu, melaksanakan tugas-tugas kelas yang menjadi tanggung jawab siswa, menaati peraturan kelas, mengumpulkan tugas tepat waktu, berpakaian sopan dan rapi. Berdasarkan pengamatan yang dilakukan peneiti pada hari Selasa tanggal 10 Maret 2020, terlihat masih terdapat beberapa siswa yang karakter disiplinnya belum sepenuhnya berkembang di dalam 
kelas hal ini dikarenakan beberapa faktor diantaranya faktor internal dan eksternal. Faktor internal faktor yang berasal dari dalam diri siswa yaitu siswa belum sepenuhnya terbiasa untuk selalu disiplin di dalam kelas, lalu faktor kedua yakni faktor eksternal yaitu faktor yang berasal dari luar diri siswa yakni seperti faktor lingkungan karena di depan kelas terdapat kantin. Jadi, siswa dengan mudahnya keluar masuk kantin tanpa menghiraukan apakah bel masuk telah berbunyi atau belum karena jarak antara kantin dan kelas sangat berdekatan. Melihat keadaan tersebut guru memotivasi siswa mengingatkan siswa agar agar selalu masuk kelas tepat waktu.

Sebagai motivator guru juga telah memotivasi siswa agar melaksanakan tugastugas kelas yang menjadi tanggung jawab siswa hal ini terlihat ketika sebelum bel masuk berbunyi guru menyempatkan diri untuk memperhatikan kebersihan kelas dan memeriksa siapa saja siswa yang piket kelas, disamping itu guru juga terlihat memotivasi siswa agar melaksanakan tugas-tugas kelas yang sudah menjadi tanggung jawabnya seperti halnya menjaga kebersihan kelas dan melaksanakan piket kelas sesuai dengan jadwal dan tanggung jawab masing-masing siswa. Sebagai motivator guru juga telah memotivasi siswa agar menaati peraturan yang ada di dalam kelas hal ini terlihat ketika saat proses pembelajaran sedang berlangsung semua siswa terlihat tertib dari awal pembelajaran sampai dengan selesai. Melihat itu guru kemudian memotivasi semua siswa yang ada di kelas untuk selalu mempertahankan ketertiban kelas. Begitupun setelah jam istirahat selesai guru masuk kembali ke dalam kelas melihat kondisi kelas yang masih terlihat bersih dan rapi guru kemudian memberikan sedikit pujian kepada semua siswa yang berada di dalam kelas. Kemudian guru juga telah melakukan perannya sebagai motivator dengan memberikan dorongan kepada siswa agar memakai pakaian seragam sesuai dengan aturan sekolah. Terlihat ketika sebelum masuk kelas siswa berbaris di depan kelas untuk memeriksa kerapian diri salah satunya kerapian dalam berpakaian. Sambil memeriksa kerapian diri guru selalu memberikan motivasi berupa nasihat agar semua siswa memakai pakaian yang sopan dan rapi sesuai dengan pakaian seragam sekolah setiap hari.

\section{Peran Guru Sebagai Fasilitator}

Berdasarkan penelitian yang telah dilakukan peneliti di kelas IV A SDN 01 Kota Bengkulu melalui observasi, wawancara dan dokumentasi terlihat guru telah melakukan perannya sebagai fasilitator yaitu dengan menyediakan fasilitas yang butuhkan siswa dalam mengembangkan karakter disiplinnya. Fasilitas yang telah di sediakan guru di antaranya menyiapkan media pembelajaran sesuai dengan materi yang akan dipelajari, membuat tata tertib di dalam kelas, memberikan tindakan kepada siswa agar menaati peraturan kelas, menentukan target waktu untuk siswa agar mengumpulkan tugas tepat waktu, memberikan contoh dalam berpakaian sopan dan rapi. Sebagai fasilitator guru telah menyediakan fasilitatas yang dibutuhkan siswa dalam mengembangkan karakter disiplin pada siswa hal ini terlihat ketika sebelum memulai kegiatan pembelajaran guru telah menyediakan media pembelajaran yang sesuai dengan materi yang akan di pelajari seperti pada hari pertama guru telah meyediakan media pembelajaran dengan menggunakan media konkret yaitu berupa timbangan dan buah-buahan lalu hari kedua guru juga menggunakan benda konkret yaitu berupa bangun ruang ada banyak bangun ruang yang digunakan guru seperti bangun ruang kubus, balok, dan segitiga. Guru menggunakan media pembelajaran dengan tujuan agar siswa tertarik untuk belajar dan keinginan untuk belajarpun akan semakin tinggi karena rasa ingin tahu siswa tentang pelajaran akan menjadi lebih tinggi. Di dalam kelaspun guru juga telah membuat tata tertib ini dilakukan agar siswa selalu di siplin dan selalu mematuhi aturan yang ada di dalam kelas. terlihat guru juga selalu memberikan tindakan kepada siswa agar menaati peraturan yang ada di dalam kelas berdasarkan 
penelitian yang telah dilakukan peneliti pada hari Kamis tanggal 12 Maret 2020 terlihat masih ada siswa yang belum menaati peraturan kelas siswa seperti ketika proses pembelajaran sedang berlangsung terdapat dua orang siswa yang kedapatan sedang sibuk bermain sendiri di bangkunya melihat itu guru memberikan tindakan kepada siswa tersebut dengan memberikan teguran kepada siswa tersebut agar menaati peraturan yang ada di dalam kelas. Setelah menyampaikan materi guru juga terlihat memberikan tugas kepada semua siswa dan menentukan pukul berapa tugas tersebut harus dikumpulkan misal sebelum bel istirahat berbunyi tugas tersebut sudah harus dikumpulkan. Selanjutnya guru juga selalu memberikan contoh kepada siswa salah satunya dari segi berpakaian terlihat pada hari senin guru memakai baju seragam pdh, hari rabu memakai baju batik, jumat memakai pakaian muslim dan hari sabtu memakai baju pramuka.

\section{Peran Guru Sebagai Evaluator}

Berdasarkan penelitian yang telah dilakukan peneliti di kelas IV A SDN 01 Kota Bengkulu diperoleh informasi bahwa guru telah melakukan perannya sebagai evaluator dengan menilai sikap disiplin siswa agar masuk kelas tepat waktu, menilai sikap siswa dalam melaksanakan tugas-tugas kelas yang menjadi tanggung jawabnya, menilai sikap siswa dalam menaati peraturan kelas, menilai sikap siswa agar selalu mengumpulkan tugas tepat waktu dan menilai sikap siswa dalam berpakaian sopan dan rapi. Terlihat selama melakukan penelitian sebelum memulai kegiatan pembelajaran guru selalu memeriksa daftar hadir siswa Dari situlah guru melihat dan menilai siapa saja siswa yang sering masuk kelas tepat waktu dan siapa saja siswa yang sering terlambat masuk kelas. peran guru sebagai evaluator selanjutnya yaitu melihat dan menilai siswa dalam melaksanakan setiap tugas kelas yang memang sudah menjadi tanggung jawab masing-masing siswa salah satunya piket kelas. Terlihat setiap hari Sabtu semua siswa rutin melaksanakan senam pagi di halaman sekolah. Setelah melakukan kegiatan senam semua siswa melakukan kebersihan kelas dengan di dampingi wali kelas masing-masing. Agar kebersihan kelas cepat selesai guru membagi siswa menjadi beberapa kelompok ada yang bertugas membersihkan ruangan dalam kelas, ada yang bertugas membersihkan halaman kelas dan ada yang bertugas membersihkan taman kelas. Selama melakukan kebersihan guru melihat siapa saja siswa yang sungguh-sungguh melakukan kebersihan dan siapa saja siswa yang hanya bermain-main.

Kemudian sebagai evaluator guru juga melihat dan menilai siapa saja siswa yang menaati peraturan di dalam kelas dan siapa saja siswa yang tidak menaati peraturan yang ada di dalam kelas. Terlihat setelah bel masuk berbunyi semua siswa masuk seperti biasa ke dalam kelas untuk melaksanakan kegiatan pembelajaran, selama proses pembelajaran guru melihat siapa saja siswa yang aktif dan siswa yang hanya bermain-main selama pembelajaran dan tidak menaati peraturan kelas. Dari situlah guru dapat melakukan penilaian kepada siswa siapa saja siswa yang menaati peraturan kelas dan siapa saja siswa yang belum menaati praturan yang ada di kelas. Guru juga telah melakukan perannya sebagai evaluator dengan melihat dan menilai siapa saja siswa yang mengumpulkan tugas dengan tepat waktu. Hal ini terlihat ketika guru memberikan tugas guru melihat dan melakukan penilaian kepada siswa dalam mengumpulkan tugas. Begitupun dalam memakai seragam sekolah sebelum masuk kelas guru selalu memeriksa kerapian diri siswa salah satunya kerapian dalam berpakaian. Dari situlah guru bisa menilai siapa saja siswa yang sering memakai pakaian sesuai dengan aturan sekolah dan siapa saja siswa yang sering tidak memakai pakaian sesuai dengan aturan sekolah.

\section{Pembahasan}

Berdasarkan pengumpulan dan teknik analisis data yang telah dilakukan, maka telah diperoleh informasi secara jelas tentang bagaimana peran guru dalam 
mengembangkan karakter disiplin siswa. Pada bagian pembahasan ini, akan diuraikan beberapa teori yang relevan dengan penelitian ini. Melalui teori-teori tersebut, peneliti akan mendeskripsikan secara lebih rinci mengenai hasil penelitian yang telah di dapat. Pembahasan hasil penelitian tersebut adalah sebagai berikut.

\section{Peran Guru sebagai Motivator}

Dari hasil temuan yang telah dilakukan oleh peneliti melalui observasi, wawancara dan dokumentasi, bahwa peran guru sebagai motivator telah dilakukan di dalam kelas IV A. Sebelum memulai kegiatan pembelajaran guru selalu menyempatkan diri untuk memberikan dorongan semangat kepada siswa agar masuk kelas tepat waktu, melaksanakan tugas-tugas kelas yang menjadi tanggung jawab siswa seperti piket kelas sesuai dengan jadwal masing-masing siswa, menaati peraturan kelas, mengumpulkan tugas tepat waktu, berpakaian sopan dan rapi sesuai dengan aturan sekolah. Walaupun guru telah melakukan perannya sebagai motivator namun masih ada beberapa siswa yang karakter disiplinnya belum sepenuhnya berkembang di dalam kelas hal ini terlihat ketika bel masuk berbunyi masih ada beberapa siswa yang terlambat masuk kelas. Untuk mengatasi permasalahan tersebut peran guru sebagai motivator sangat penting bagi siswa, guru bukan hanya memberikan motivasi ketika siswa melakukan kesalahan saja melainkan guru harus bisa memberikan motivasi secara terus menerus kepada siswa terutama dalam mengembangkan karakter yang ada pada diri siswa salah satunya karakter disiplin hal ini dilakukan agar siswa selalu terbiasa untuk selalu disiplin dalam mengerjakan sesuatu yang sudah menjadi kewajiban dan tanggung jawabnya. Sesuai dengan pendapat Manizar dalam penelitiannya (2015:16) hasil penelitian tersebut menunjukkan bahwa guru sebagai motivator artinya guru harus memberikan dorongan kepada siswa dalam rangka meningkatkan kegairahan dan pengembangan kegiatan belajar siswa, guru sebagai motivator harus merangsang dan memberikan dorongan serta reinforcement untuk membangkitkan kembali gairah dan semangat belajar siswa.

Hal ini di perkuat dengan pendapat Sundari dalam penelitiannya (2017:63) hasil penelitian tersebut menunjukkan sebagai motivator guru harus mampu memberikan rangsangan, dorongan serta reinforcement secara terus menerus kepada siswa hal tersebut dilakukan untuk mengembangkan potensi, menumbuhkan swadaya (aktivitas), dan daya cipta (kreativitas) sehingga akan terjadi dinamika dalam proses belajar. Peran guru sebagai motivator guru harus mampu memberikan motivasi kepada siswa untuk selalu disiplin di kelas diantaranya guru harus mampu mendorong siswa agar masuk kelas tepat waktu, melaksanakan tugas-tugas kelas yang menjadi tanggung jawabnya, menaati peraturan kelas, mengumpulkan tugas tepat waktu, dan memberikan dorongan agar berpakaian sopan dan rapi.

Sesuai dengan pendapat Kurniati dalam jurnal penelitiannya (2020:41) diperoleh hasil bahwa sebagai motivator guru harus dapat memotivasi siswa agar datang tepat waktu ke sekolah. Oleh karena itu, peran guru sangat penting bagi perkembangan diri siswa dikarenakan sudah menjadi tugas dan tanggung jawab seorang guru di sekolah. Hal Ini diperkuat dengan pendapat Julia dalam penelitiannya (2019:120) hasil penelitian tersebut menunjukkan setiap guru mempunyai peran dalam meningkatkan dan mengembangkan disiplin dan nilai karakter pada siswa karena memang dituntut dari pihak sekolah, seperti menasehati anak dengan lemah lembut dan berulang-ulang kali agar bisa dipahami oleh siswa.

\section{Peran Guru sebagai Fasilitator}

Dari hasil temuan yang telah dilakukan peneliti melalui observasi, wawancara dan dokumentasi, bahwa guru telah melakukan perannya sebagai fasilitator di dalam kelas IV A dengan menyediakan fasilitas yang dibutuhkan siswa dalam mengembangkan karakter disiplinnya. Di antaranya menyiapkan media 
pembelajaran sesuai dengan materi yang akan dipelajari, membuat tata tertib di dalam kelas, memberikan tindakan kepada siswa dalam menaati peraturan kelas, menentukan target waktu untuk siswa agar mengumpulkan tugas tepat waktu, serta memberikan contoh dalam berpakaian sopan dan rapi. Sebagai fasilitator guru harus mampu menyediakan fasilitas yang mendukung yang sesuai dengan kebutuhan siswa dalam mengembangkan karakter disiplinnya. Salah satunya menyediakan sumber belajar yang menarik agar siswa tertarik untuk belajar sehingga akan berdampak pada karakter disiplin siswa. Sesuai dengan pendapat Maeliah dalam jurnal penelitiannya (2012:175) dengan hasil yang diperoleh bahwa sebagai fasilitator guru hendaknya mampu mengusahakan sumber belajar yang berguna serta menunjang pencapaian tujuan dan proses belajar-mengajar pada siswa.

Hal ini diperkuat oleh pendapat Djamarah (2005:46) sebagai fasilitator guru hendaknya dapat menyediakan fasilitas yang memungkinkan kemudahan kegiatan belajar pada siswa. karena lingkungan belajar yang tidak menyenangkan, suasana ruang kelas yang pengap, meja dan kursi berantakan, fasilitas belajar yang kurang tersedia dapat menyebabkan siswa menjadi malas untuk belajar. Sebagai fasilitator guru harus mampu menyediakan fasilitas yang dibutuhkan siswa dalam mengembangkan karakter disiplinnya di antaranya menyiapkan media pembelajaran yang menarik, memberikan tindakan kepada siswa agar melaksanakan tugas-tugas kelas yang menjadi tanggung jawabnya, memberikan tindakan kepada siswa agar menaati peraturan kelas, menentukan target waktu untuk siswa agar mengumpulkan tugas tepat waktu, memberikan contoh dalam berpakaian sopan dan rapi. Hal ini sesuai dengan pendapat Sundari dalam jurnal penelitiannya (2017:75) diperoleh hasil bahwa peran guru sebagai fasilitator yaitu guru harus mampu mengolah kelas dan membangkitkan suasana proses pembelajaran dengan model pembelajaran yang bervariatif yang disesuaikan dengan usia peserta didik. artinya dengan menggunakan model pembelajaran yang bervariasi siswa akan lebih tertarik untuk belajar dan terdorong untuk selalu masuk kelas tepat waktu. Sama halnya dengan adanya tata tertib di dalam kelas. semua siswa akan merasa ada tanggung jawab yang harus mereka patuhi selama di dalam kelas. Hal ini sesuai dengan pendapat Ningsih dalam jurnal penelitiannya (2019:66) hasil penelitian tersebut menunjukka bahwa guru membuat tata tertib dengan tujuan agar siswa selalu menaati peraturan dan menjaga ketertiban yang ada baik di sekolah maupun di kelas. Jika ada siswa yang melakukan peranggaran terhadap peraturan/tata tertib sekolah maka harus segera ditindak dengan memberikan teguran. Apabila siswa masih tetap melakukan pelanggaran, maka diberikan sanksi sesuai dengan peraturan tata tertib yang telah di sepakati bersama.

\section{Peran Guru Sebagai Evaluator}

Dari hasil temuan yang telah dilakukan peneliti melalui observasi, wawancara dan dokumentasi, bahwa peran guru sebagai evaluator telah dilakukan di dalam kelas IV A. Hal ini terlihat ketika sebelum memulai kegiatan pembelajaran guru selalu memeriksa daftar hadir siswa, memeriksa kebersihan yang ada di sekeliling kelas, kemudian melihat siapa saja siswa yang aktif dan siswa yang hanya bermain-main selama pembelajaran serta tidak menaati peraturan yang ada di dalam kelas. Dari hasil evaluasi tersebut guru bisa melihat dan menilai sejauh mana perkembangan karakter disiplin pada siswa serta rasa tanggung jawab siswa terhadap kewajiban dan tugasnya masing-masing di dalam kelas. Oleh karena itu, sebagai evaluator guru harus mampu memberikan penilaian secara terus menerus kepada siswa bukan hanya dari segi ilmu pengetahuan saja melainkan dari sikap dan perilaku setiap siswa hal tersebut dilakukan untuk melihat dan menilai sejauh mana perkembangan karakter disiplin siswa di dalam kelas. Sesuai dengan pendapat Arifudin dalam jurnal penelitiannya (2015: 186) hasil penelitian tersebut menunjukkan guru sebagai evaluator memiliki peran untuk melihat hasil kerja 
siswa serta mengikuti perkembangan siswa secara terus menerus agar guru dapat memperbaiki karakter pada diri siswa menjadi individu yang berkarakter disiplin, jujur dan bertanggung jawab. Hal ini diperkuat dengan pendapat Saleh (2012: 6) dengan hasil penelitian bahwa peran guru sebagai evaluator berarti setiap guru dituntut untuk mampu mengevaluasi sikap atau perilaku yang ada pada diri siswa. Penilaian dilakukan untuk melihat sejauh mana perkembangan karakter disiplin pada siswa.

\section{Kesimpulan}

Secara teoretis dan praktis pada penelitian tentang peran guru sebagai pendidik dalam mengembangkan karakter disiplin siswa di kelas IV A SDN 01 Kota maka dapat diperoleh kesimpulan sebagai berikut:

1. Sebagai motivator guru telah melakukan perannya dengan memotivasi siswa agar selalu masuk kelas tepat waktu, melaksanakan tugas-tugas kelas yang menjadi tanggung jawabnya salah satunya tugas piket kelas sesuai dengan tanggung jawab siswa, menaati peraturan kelas, mengumpulkan tugas dengan tepat waktu, dan berpakaian yang sopan dan rapi sesuai dengan aturan sekolah.

2. Sebagai fasilitator guru juga telah menyediakan fasilitas yang dibutuhkan siswa dalam mengembangkan karakter disiplinnya di dalam kelas, di antaranya menyiapkan media pembelajaran sesuai dengan materi yang akan dipelajari, membuat tata tertib di dalam kelas, memberikan tindakan kepada siswa agar menaati peraturan kelas, menentukan target waktu untuk siswa agar mengumpulkan tugas tepat waktu, memberikan contoh dalam berpakaian sopan dan rapi sesuai dengan aturan sekolah.

3. Sebagai evaluator guru juga telah melakukan perannya dengan melihat dan menilai perkembangan karakter disiplin siswa agar selalu disiplin di dalam kelas di antaranya menilai sikap disiplin siswa agar selalu masuk kelas tepat waktu, menilai sikap siswa dalam melaksanakan tugas-tugas kelas yang menjadi tanggung jawabnya, menilai sikap siswa dalam menaati peraturan kelas menilai sikap siswa agar selalu mengumpulkan tugas tepat waktu, menilai sikap siswa dalam berpakaian sopan dan rapi sesuai dengan seragam setiap hari di sekolah.

\section{Saran}

Berdasarkan penelitian yang telah dilakukan peneliti tentang peran guru sebagai pendidik dalam mengembangkan karakter disiplin siswa di kelas IV A SDN 01 Kota Bengkulu. Adapun saran yang dapat diberikan peneliti di antaranya sebagai berikut:

1. Sebagai motivator guru sebaiknya selalu memberikan motivasi setiap hari kepada siswa agar selalu disiplin di dalam kelas bukan hanya memotivasi siswa pada saat siswa melakukan kesalahan.

2. Sebagai fasiliator guru sebaiknya lebih tegas dalam mengembangkan karakter disiplin siswa salah satunya dalam memberikan tindakan kepada siswa agar menaati peraturan kelas. Karena, masih terdapat siswa yang belum menaati peraturan kelas.

3. Sebagai evaluator guru sebaiknya melakukan penilaian secara lebih terbuka agar siswa bisa memperbaiki diri dalam mengembangkan karakter disiplinnya di dalam kelas. 


\section{Referensi}

Arifudin, S, I,. (2015). Peranan Guru Terhadap Pendidikan Karakter Siswa di Kelas V SDN 01 Siluman, Jurnal Ilmiah Pendidikan Guru Sekolah Dasar, Vol. 2, No. 2, Hal. 186, Diunduh Pada Tanggal 5 Juni 2020.

Djamarah, S. B., (2005), Guru dan Anak Didik dalam Interaksi Edukatif. Jakarta: PT Rineka Cipta.

Julia, P. (2019). Peranan Guru dalam Meningkatkan Nilai Karakter Disiplin dan Kejujuran Siswa di SD Unggul Lampeunerut, Jurnal Dedikasi Pendidikan, Vol. 3, No. 2, Hal. 120. Diunduh Pada 4 Juni 2020.

Kharisma C, \& Suyatno,. (2018). Peran Guru dalam Menanamkan Karakter Disiplin Siswa di Sekolah Dasar Negeri Bleber 1 Prambanan Sleman. Jurnal Fundamental Pendidikan Dasar, E ISSN 2614-1620, Vol. 1, No. 2, Hal. 133. Diunduh Pada Tanggal 5 Juni 2020.

Kurniati, G, Y., \& Divan, S., (2020). Peran Guru dalam Membudayakan Pendidikan Karakter di Sekolah, Jurnal Literasi Pendidikan Dasar. Vol. 1, No. 1. Hal. 75. Diunduh Pada 4 Juni 2020.

Maeliah, M., (2012). Peran Guru dalam Menyiapkan Kompetensi Keja Siswa Sesuai Tuntutan Dunia Kerja di Industri Busana. Jurnal Seminar Internasional, ISSN 1907-2066, Diunduh Pada 5 Juni 2020.

Manizar, E., (2015), Peran Guru sebagai Motivator dalam Belajar. Jurnal Pendidikan Islam. Vol. 1, No. 2. Hal. 186. Diunduh pada 20 Januari 2020.

Rohman, F., (2018), Peran Pendidik dalam Pembinaan Disiplin Siswa Disekolah/Madrasah, Jurnal Universitas Islam Negeri Sumatera Utara (UINSU) Medan, Vol. 4 No. 1, Hal. 92-93, Diunduh pada 16 Januari 2020.

Saleh, M,. (2012). Peran Guru dalam Menanamkan Pendidikan Karakter Anak Usia Dini di Paud Se-Kecamatan Limboto, Jurnal Pedagogika, Vol. 3. Hal. 6. Diunduh Pada Tanggal 5 Juni 2020.

Subini, N., (2012), Awas Jangan Jadi Guru Karbitan. Yogyakarta: Javalitera.

Sundari, F., (2017), Peran Guru sebagai Pembelajar dalam Memotivasi Peserta Didik Anak Usia SD. Jurnal Pendidikan Manajemen Perkantoran. Vol. 4, No. 1. Hal. 75. Diunduh pada 20 Januari 2020.

Yulianingsih \& Darmo T, (2019) Peran Guru Pendidikan Kewarganegaraan dalam Membina Kedisiplinan Peserta Didik, Jurnal pendidikan, Vol. 17, No. 1, Hal. 66. Diunduh Pada Tanggal 5 Juni 2020. 